\title{
Tomasz Tyburcy
}

\section{Przestępstwo kradzieży w przedwojennych projektach kodeksu karnego}

Artykuł analizuje regulację przestępstwa kradzieży w przedwojennych projektach kodeksu karnego. Największe kontrowersje dotyczyły potrzeby wprowadzenia znamienia braku zgody właściciela (posiadacza) oraz klauzuli bezprawności. Ta ostatnia występuje w prawie niemieckim od 1871 r. Autor zwraca uwagę na brak konieczności tworzenia znamienia braku zgody właściciela (posiadacza), gdyż zawiera się ona w znamieniu zaboru. Zbędna jest także klauzula bezprawności przywłaszczenia, ponieważ stosują się ją w innych przypadkach. Wprowadzanie do typów czynów zabronionych znamienia bezprawności zachowania jest uzasadnione wyłącznie wtedy, kiedy określone zachowanie jest unormowane w przepisach szczególnych. Nie jest tak w przypadku kradzieży. Projekty unikały kazuistyki, która towarzyszyła unormowaniu kradzieży w dawnym europejskim prawodawstwie. Dyskusje toczyły się także nad wprowadzeniem typu uprzywilejowanego kradzieży. Kodeks karny z 1932 r. stypizował tylko dwie kradzieże kwalifikowane (kradzież rozbójniczą oraz rozbój). Okolicznością kwalifikującą nie było włamanie. W art. 257 § 2 k.k. z 1932 r. uregulowano typ uprzywilejowany kradzieży - zabór z nędzy w celu użycia małej wartości przedmiotu pierwszej potrzeby.

\section{Zarys genezy typizacji przestępstwa kradzieży}

Ustawodawstwa europejskie zasadniczo aż do początku XIX w. typizowały kradzież na wzór prawa rzymskiego i obejmowała ona kradzież, przywłaszczenie, sprzeniewierzenie, bezprawne używanie i często nawet oszustwo. Feuerbachowski kodeks karny (k.k). dla Bawarii z 1813 r. miał w tym zakresie charakter nowatorski, gdyż odróżniał kradzież od przywłaszczenia. Za postać kradzieży uznawał natomiast przywłaszczenie rzeczy znalezionej. Wyraźnie wyłączał spod zakresu pojęcia kradzieży furtum possessionis oraz świadome przyjęcie zapłaty nie istniejącego długu (§ 211). Jak podaje W. Wojciechowski, precyzyjne odgraniczenie kradzieży od sprzeniewierzenia wprowadzał k.k. dla Królestwa Pruskiego z 1851 r. Według jego § 225, kradzieżą był zabór rzeczy ruchomej innej osobie po to, aby ją przywłaszczyć. Sprzeniewierzeniem było rozporządzenie cudzą rzeczą ruchomą 
(np. sprzedaż lub używanie), której dzierżenie lub posiadanie sprawca uzyskał z obowiązkiem określonego postąpienia względem niej i właściciela (§ 225) oraz, gdy sprawca daną rzecz znalazł lub dostała się ona w jego władanie przypadkiem. Regulację tę przyjęto także w k.k. Rzeszy z 1871 r. .

Kodeks kar głównych i poprawczych z 1847 r. dla Królestwa Polskiego w art. 1147 uznawał za kradzież każdy zabór cudzej rzeczy, pieniędzy lub innych ruchomości bez użycia gwałtu i innych okoliczności rozboju lub rabunku. W ówczesnej literaturze podkreślano, że kradzież wymaga zamiaru zaboru cudzej własności ruchomej w celu przywłaszczenia, czyli „objęcia jej bez woli powrotu w takie fizyczne posiadanie, iżby ją wedle swej woli, tak jak własną, rozporządzać można” ${ }^{2}$. Nie kwalifikowano jako kradzieży zaboru rzeczy własnej zastawnikowi lub w celu zniszczenia. Zabór rzeczy własnej z władania zastawnika kwalifikowano jako oszustwo, którym zgodnie z art. 1173 był „każdy zabór cudzych rzeczy, pieniędzy lub innych ruchomości za pomocą podstępu dokonany"3. Cechą wspólną wszystkich kodeksów karnych obowiązujących na ziemiach polskich było połączenie obiektywnego działania sprawcy (zabór) z subiektywnym nastawieniem (zamiar przywłaszczenia).

Przestępstwo kradzieży jest często powoływane na wykładach z części ogólnej kodeksu karnego, gdyż wydawać by się mogło, że ma znamiona, których wykładnia nie wymaga specjalistycznej wiedzy prawniczej. Jednak po odzyskaniu przez Polskę niepodległości w doktrynie toczyły się spory związane z ustaleniem znamion kradzieży. Jedni autorzy uważali za wskazane, aby jej przedmiot wykonawczy określić zgodnie $\mathrm{z}$ terminologią cywilistyczną jako „mienie ruchome” ${ }^{4}$. Inni uznawali znamię „ruchome” za zbędne 5 .

W Kodeksie karnym z 1932 r. ${ }^{6}$ zasadnie odstąpiono od zbytniej kazuistyki. Moim zdaniem, oddzielna typizacja kradzieży jest uzasadniona wyłącznie ze względu na sposób działania sprawcy, który narusza lub naraża na niebezpieczeństwo dobra wyższego

\footnotetext{
${ }^{1}$ J. Wojciechowski., Ewolucja pojęcia przestępstwa kradzieży (rozważania historyczno-porównawcze, „Annales UMCS, Sectio G", vol. XXIV (1977), s. 175 i n.

${ }^{2}$ F. Maciejowski, Wykład prawa karnego w ogólności z zastosowaniem Kodeksu Kar Głównych i Poprawczych, Warszawa 1848, s. 480 i n.

${ }^{3}$ Ibidem, s. 499.

${ }^{4}$ Tak przyjęto w k.k. z 1932 r. Tak też projekt W. Makowskiego, Komisja Kodyfikacyjna Rzeczpospolitej Polskiej. Sekcja prawa karnego. Projekt Kodeksu Karnego. Uzasadnienie części szczególnej, t. V, z. 1, Warszawa 1926, s. 38.

${ }^{5}$ Zob. Komisja Kodyfikacyjna Rzeczpospolitej Polskiej. Sekcja prawa karnego. Projekt Kodeksu Karnego. Uzasadnienie części szczególnej, t. V, z 4, Warszawa 1930, s. 216-220.

${ }^{6}$ Rozporządzenie Prezydenta Rzeczypospolitej z dnia 11 lipca 1932 r. - Kodeks karny (Dz.U. 1932 nr 60 poz. 571), dalej k.k. z 1932 r.
} 
rzędu niż mienie. Inne okoliczności powinny być uwzględniane przy wymiarze kary. Wydaje się, że kazuistyczne tendencje, które towarzyszyły unormowaniu przestępstwa kradzieży, mają swój rodowód w prawie rzymskim. Nawet w XIX w. europejskie kodeksy karne wyodrębniały szereg okoliczności kwalifikujących kradzież. Można je podzielić na kilka grup. Do pierwszej należą przypadki związane z trudnością w zabezpieczeniu mienia, które mogły wynikać z zewnętrznych okoliczności (znajdowanie się na otwartej przestrzeni). Wyższe ustawowe zagrożenie karne przewidywano w przypadku kradzieży mienia, którego nie można było w sposób szczególny zabezpieczyć ze względu na okoliczności zewnętrzne (pora nocna, przedmiot wykonawczy $\mathrm{w}$ postaci drzewa, ryb, zwierząt gospodarczych, płodów i owoców, minerałów, elementów infrastruktury kolejowej). Drugą grupę stanowiły kradzieże związane ze szczególnym stosunkiem sprawcy do mienia (np. służącego lub innej osoby przebywającej w domu pokrzywdzonego). Do trzeciej natomiast należały kradzieże kwalifikowane ze względu na sposób działania sprawcy (niebezpieczne i podstępne). Do takich okoliczności zaliczano: gwałt, uzbrojenie (furtum armatum), podstęp, włamanie oraz tzw. przemyślne wejście (np. przez okno, parkan, podkop) stypizowane w art. 1659 k.k. obowiązującego w zaborze austriackim. Ze względu na naturę przedmiotu wykonawczego typem kwalifikowanym była kradzież przedmiotów związanych z kultem religijnym (art. 588 K.K.R. ${ }^{7}, \S 243$ K.K.N. ${ }^{8}$, $\S 175$ U.K.A. ${ }^{9}$ ). Kodeksy państw zaborczych przewidywały także typ kwalifikowany kradzieży rzeczy podróżnemu (np. w pociągu).

W XIX-wiecznej nauce prawa często nie rozdzielano jeszcze kwestii charakterystyki czynu, determinującej kwalifikację pod dany typ, od cechy osoby sprawcy, wpływającej na nadzwyczajny wymiar kary. Dlatego np. k.k. austriacki z 1852 r. kwalifikował jako zbrodnie trzecią kradzież oraz tę popełnioną „zawodowo”, a kradzież w typie podstawowym stanowiła jedynie przekroczenie (odpowiednik występku). Okolicznością kwalifikującą było także popełnienie kradzieży w bandzie utworzonej w tym celu ${ }^{10}$.

\footnotetext{
${ }^{7}$ Kodeks karny rosyjski z 1866 r., dalej K.K.R.

${ }^{8}$ Kodeks karny niemiecki z 1871 r. , dalej K.K.N.

${ }^{9}$ Ustawa karna austriacka $\mathrm{z}$ dnia 27 maja 1852 r., dalej U.K.A.

${ }^{10}$ Kodeks karny z 1997 r. recydywę i ,zawodowość” (popełnianie przestępstw jako stałe źródło dochodu) oraz popełnienie przestępstwa w zorganizowanej grupie albo związku mającym na celu popełnienie przestępstwa traktuje jako okoliczność obostrzającą karę w odniesieniu do wszystkich występków (art. 64 i 65 k.k.). Branie udziału w zorganizowanej grupie lub związku mającym na celu popełnienie przestępstwa, w tym skarbowego zostało stypizowane jako przestępstwo (art. 258 k.k.).
} 


\section{Brak zgody właściciela (posiadacza) jako znamię kradzieży}

W pracach nad projektem przedwojennego k.k. proponowano, aby expressis verbis ustanowić w ustawie znamię braku zgody właściciela ${ }^{11}$. Pomysł ten, trafnie zresztą, nie zyskał poparcia. Po pierwsze dlatego, że brak zgody właściciela wkomponowany jest w znamię zaboru $^{12}$. Po drugie, pokrzywdzonym tym przestępstwem może być także osoba niebędąca właścicielem (władający rzeczą). Trafnie zwracano uwagę, że „wbrew jednolitemu stanowisku teorii i orzecznictwa, ustalonego pod mocą obowiązujących kodeksów, gdzie podkreślany jest przy kradzieży brak zgody posiadacza, projekt wysuwa czynnik braku zgody właściciela. Określenie to zastępuje spotykane gdzieindziej wzmianki o bezprawności działania przy kradzieży. Jednakże określenie to nie jest dostateczne i nie wyczerpuje całkowicie pojęcia bezprawności zamiaru przy kradzieży, wymienia bowiem kazuistycznie jedną tylko z cech bezprawności, a przytem cechę nie istotną"13. Podkreślano, że gdyby uznać potrzebę takiego właśnie określenia, należałoby raczej pójść za wzorem U.K.A. z 1852 r. i posłużyć się terminem „bez zgody posiadacza”. Krytycy takiego znamienia (bez zgody posiadacza) podnosili, że posiadanie jest pojęciem prawa cywilnego i nie nadaje się do określenia znamion przestępstwa. Proponowali oni pojęcie dzierżyciela, którego używało orzecznictwo wydane na gruncie K.K.N. z 1871 r. Wprowadzenie cywilistycznego pojęcia właściciela uważano za znacznie niebezpieczniejsze i niepotrzebne ${ }^{14}$. Słusznie wskazywano, że nie wypełniają znamion kradzieży przypadki, w których sprawca, po uprzednim porozumieniu się z właścicielem, zabiera rzecz spod władztwa posiadacza i dlatego termin „bez zgody właściciela” jest zbędny ${ }^{15}$.

Wydaje się, że znamię braku zgody właściciela (posiadacza) jest niefortunne, ponieważ, jeżeli określona osoba ma prawo do władania rzeczą (np. komornik), to przejęcie nad nią władztwa, nawet bez zgody posiadacza, nie wypełnia znamion kradzieży. M. Siewierski trafnie podkreśla, że wyrazy „bez zgody właściciela” nie określają dostatecznie

\footnotetext{
${ }^{11}$ Projekt W. Makowskiego, Komisja Kodyfikacyjna Rzeczpospolitej Polskiej. Sekcja prawa karnego. Projekt Kodeksu Karnego... s. 38 oraz J. Makarewicza, Komisja Kodyfikacyjna Rzeczpospolitej Polskiej, Sekcja Prawa Karnego, Projekt wstęny części szczegółowej Kodeksu karnego, t. IV, z. 2, Lwów 1926 r., s. 31.

${ }^{12}$ Już w wieku XVIII przyjmowano, że słowo brać jako znamię kradzieży ,domyślać się każe brakującego na to zezwolenia”. Zob. W. Blackstone, Prawo Kryminalne Angielskie, Warszawa 1786 s. 314-15. Już w tamtym okresie odróżniano od kradzieży „złośliwe zaufania wzajemnego zażycie”, któremu odpowiadać mogło np. sprzeniewierzenie.

${ }^{13}$ M. Siewierski (w:) Włodzimierz Sokalski (red.), Opinje o Projekcie Kodeksu Karnego, Warszawa 1931, nr 5, s. 3-4.

${ }^{14}$ Ibidem, s. 3-4.

${ }^{15}$ Ibidem, s. 3-4.
} 
ani wyczerpująco cechy bezprawności zamiaru przy kradzieży ${ }^{16}$. Omawiana przesłanka nie została wyeksponowana expressis verbis w art. 257 § 1 k.k. z 1932 r., lecz przepis ten stanowił o zaborze cudzego mienia ruchomego innej osobie. Wydaje się, że znamię ,innej osobie" także należy uznać za zbędne i wystarczające było wskazanie, że przedmiot kradzieży to ,cudze mienie”.

Znamię braku zgody uprawnionego występuje w art. 278 § 2 obowiązującego Kodeksu karnego ${ }^{17}$. Wynika to, moim zdaniem, z tego, że w znamię „uzyskania”, w przeciwieństwie do terminu ,zabór” z art. 278 § 1 k.k., nie jest wkomponowany brak zgody uprawnionego. Dlatego też ustawodawca trafnie wprowadził „brak zgody osoby uprawnionej” do przepisu typizującego tzw. kradzież programu komputerowego.

\section{Znamię bezprawności celu działania}

Najbardziej, moim zdaniem, istotny spór dotyczył kwestii bezprawności działania (bezprawności celu działania). Polski ustawodawca, konsekwentnie od k.k. z 1932 r., nie wprowadza do typu kradzieży expressis verbis znamienia bezprawności działania. Nie wzoruje się on na prawie niemieckim, w którym już od k.k. z 1871 r. strona podmiotowa kradzieży określona jest sformułowaniem ,aby ją sobie bezprawnie przywłaszczyć” ${ }^{18}$.

Jak podkreśla J. Wojciechowski, bezprawność zaboru wynika z jego istoty i dlatego zbędne jest eksponowanie $\mathrm{w}$ treści przepisu, że ma on nastąpić „bez zgody posiadacza” lub, iż działaniu sprawcy ma przyświecać cel „bezprawnego przywłaszczenia”. Powołany autor trafnie wskazuje, że wyrażenie zgody na „zabór” wyłącza sam „zabór”, a nie bezprawność czynu ${ }^{19}$. Wyłączona jest więc istota czynu.

Trafnie wskazał M. Siewierski, że ,wprowadzanie do definicji kradzieży expressis verbis cechy bezprawności zamiaru jest zbędne. (...) Komisja zajęła wyraźne stanowisko, iż istnieją takie przestępstwa, przy których wprowadzanie cechy bezprawności jest konieczne (np. pozbawienie wolności, zmuszenie, samowola), że natomiast istnieje inna kategoria przestępstw (jak np. zabójstwo), przy których użycie tradycyjnego wyrazu «bezprawnie» jest zbędne, ponieważ jest rzeczą zupełnie oczywistą, iż karą zagrożone jest jedynie takie

\footnotetext{
${ }^{16}$ Ibidem, s. 3-4.

${ }^{17}$ Ustawa z 6.6.1997 r. - Kodeks karny, Dz.U. 1997 nr 88 poz. 553 z późn. zm., obecnie t.j. Dz.U. z 2016 r. poz. 1137 z późn. zm.

${ }^{18}$ Zob. § 242 StGB oraz M. Siewierski (w:) Włodzimierz Sokalski (red.), op. cit., s. 3-4, gdzie powołany jest Kodeks Karny Niemiecki z 1871 r. Autor podkreśla, że w K.K.N. z 1871 r. znamię bezprawności działania występuje w przestępstwach: zniewolenia, wymuszenia, rozboju, sprzeniewierzenia, oszustwa i wielu innych.

19 J. Wojciechowski, Analiza pojęcia ,zaboru” jako elementu kradzieży, „Annales UMCS, sectio G”, vol. 16 (1969), s. 297.
} 
działanie, które przedsięwzięto w bezprawnym zamiarze. Stojąc na stanowisku, przyjętem przez naszą Komisję, twierdzę, że kradzież należy właśnie do tej drugiej kategorji przestępstw" ${ }^{20}$. Na tym kończą się wypowiedzi doktryny na temat tej tak istotnej dogmatycznie kwestii.

Moim zdaniem, wprowadzanie do typów czynów zabronionych znamienia bezprawności zachowania lub „,bezprawności zamiaru” (jeżeli przyjąć, że przywłaszczenie nie jest znamieniem kradzieży) jest uzasadnione wyłącznie w przypadkach, w których dane zachowanie jest regulowane przez przepisy szczególne. Wtedy ustawodawca posługuje się terminami „bezprawnie”, „bez uprawnienia”, „bez zezwolenia” etc. Bezprawność kradzieży wyznacza natomiast, co do zasady, brak zgody posiadacza. Jest on wkomponowany w językowe znaczenie terminu ,zabór”.

Problem powstaje jednak w sytuacjach, w których posiadacz nie wyraża zgody na przejęcie władztwa, a przejmujący jest uprawniony do posiadania rzeczy. Wyłącznie dla takich przypadków uzasadnione wydaje się rozwiązanie przyjęte w prawie niemieckim (,aby rzecz sobie bezprawnie przywłaszczyć”). Innym sposobem rozwiązania tego problemu jest nieuznawanie legalnego przejęcia władztwa za zabór. Taka wykładnia chyba jest jednak sprzeczna $\mathrm{z}$ językiem powszechnym, bowiem np. komornik zabiera rzecz bez zgody posiadacza. Dokonuje on więc legalnego zaboru. Powyższe rozważania mogą jednak okazać się bezprzedmiotowe, a niemieckie rozwiązanie niepotrzebne, jeżeli przecząco odpowiemy na następujące pytanie. Czy można być uprawnionym do „przywłaszczenia” rzeczy bez zgody władającego? Wszak użytkownik zabiera rzecz właścicielowi, żeby ją używać, a nie żeby ją przywłaszczyć. Zastawnik zabiera przedmiot zastawu w celu zabezpieczenia roszczenia, a nie w celu przywłaszczenia. Wreszcie, komornik nie zabiera rzeczy w celu przywłaszczenia, gdyż jest jedynie dzierżycielem i działa na rzecz innego podmiotu ${ }^{21}$. Natomiast w sytuacji, w której po zawarciu umowy sprzedaży rzeczy oznaczonej co do tożsamości ${ }^{22}$, sprzedający odmawia jej wydania nabywca jest uprawniony do jej zaboru. Nie działa on jednak w celu przywłaszczenia, gdyż jest już właścicielem rzeczy. Rzecz taka nie jest cudza dla nowego właściciela, a więc zdekompletowana jest strona przedmiotowa kradzieży i nie trzeba już rozstrzygać, czy przywłaszcza on tę rzecz.

\footnotetext{
${ }^{20}$ M. Siewierski (w:) Włodzimierz Sokalski (red.), op. cit., s. 3-4,

${ }^{21}$ Co prawda, czerpie dochód ze zlicytowanej rzeczy, lecz trudno uznać to za realizację uprawnień właścicielskich. Jego wynagrodzenie wynika z ustawy, a nie z tego, że zaspokajając się ze zlicytowanej rzeczy realizuje uprawnienia właściciela.

${ }^{22}$ Kupujący jest właścicielem, nawet przed zapłaceniem ceny. Wydaje się, że sprzedający ma prawo nie wydać jej, aż do otrzymania zapłaty, lecz gdy kupujący zabierze ją wbrew jego woli przed zapłaceniem ceny, to nie wypełni znamion kradzieży (brak spełnienia przesłanki „cudza”), lecz bezprawnie naruszy posiadanie sprzedającego (art. 342 k.c.).
} 
Także ze względu na subsydiarny charakter prawa karnego, uprawniony do władania rzeczą, który przejmuje nad nią władztwo w celu legalnego cywilnie, czy administracyjnie „przywłaszczenia”, nie może działać bezprawnie prawnokarnie. Moim zdaniem, należy wtedy odstąpić od potocznego rozumienia terminu „przywłaszczenie”, gdyż ma on znaczenie techniczno-prawne, z którym związany jest brak podstawy prawnej. Natomiast „legalne przywłaszczenie” określa się w języku prawnym nie jako przywłaszczanie, lecz jako nabycie prawa własności, bowiem złodziej przywłaszczając rzecz nie nabywa jej prawa własności.

\section{Typ uprzywilejowany i dekryminalizacja kradzieży (wykroczenie kradzieży)}

W przedwojennej doktrynie dyskutowano nad wprowadzeniem typu uprzywilejowanego kradzieży i wykroczenia kradzieży. W jednym z projektów jako wykroczenie stypizowano czyn polegający na zaborze cudzego mienia małej wartości przez lekkomyślność, z nędzy, celem niezwłocznego spożycia lub dla zaspokojenia zachcianki ${ }^{23}$. Inny z projektów stanowił natomiast, że „kto przez lekkomyślność, z nędzy lub dla natychmiastowego spożycia zabiera rzecz cudzą znikomej wartości, będzie karany...,24. Natomiast projekt J. Makarewicza z 1926 r., stanowił, że ,jeżeli winny zabrał celem spożycia potrawy lub napoje małej wartości, sąd może odstąpić od wymierzenia kary"25.

Łagodniejsza ocena prawna i karalność czynów polegających na zabraniu żywności w celu spożycia występuje w systemach prawnych całego świata od samego początku ich tworzenia. W literaturze podkreślono, że „kategorią czynów podobnych do kradzieży, ale karanych znacznie łagodniej lub wcale nie karanych, jest zabranie żywności celem spożycia. Według prawa germańskiego, podróżnemu wolno było jeść jagody i owoce w nieznacznej ilości, tak samo jak człowiek głodny mógł zabrać trochę żywności, jednakże (jak stanowiło prawo wizygockie) nie więcej niż dwa razy. Przepisy o łagodnym

\footnotetext{
${ }^{23}$ Zob. art. 41. Komisja Kodyfikacyjna Rzeczpospolitej Polskiej. Sekcja Prawa Karnego, Projekt przygotowawczy ustawy o wykroczeniach. Uzasadnienie, Warszawa 1929-1930, s. 69. Niektórzy autorzy opowiadali się za nietworzeniem typu wykroczenia kradzieży, a wymienione w art. 41 projektu okoliczności proponowano przenieść (z pominięciem wyrazów „dla zaspokojenia zachcianki” do przepisu typizującego typ uprzywilejowany kradzieży w k.k. Zob. M. Siewierski (w:) Włodzimierz Sokalski (red.), op. cit., s. 11-12.

${ }^{24}$ Projekt S. Rappaporta, Komisja Kodyfikacyjna Rzeczpospolitej Polskiej, Sekcja Prawa Karnego, Projekt wstępny ustawy o wykroczeniach, Warszawa 1930, t. IV, z. 4, s. 96-97. Powołany autor podkreślał, że chodziło wydzielenie z k.k. i o umieszczenie w ustawie o wykroczeniach takiego rodzaju kradzieży, który, z uwagi na jego charakter, nie powinien być uważany za czyn hańbiący połączony z karą więzienia. Chciał on także uniknąc uprawnienia sądu do odstąpienia wymierzenia kary, które, jak pokazała praktyka, było stosowane dość dowolnie

${ }^{25}$ Komisja Kodyfikacyjna Rzeczpospolitej Polskiej, Sekcja Prawa Karnego, Projekt wstępny części szczegótowej Kodeksu karnego, t. IV, z. 2, Lwów 1926, s. 31.
} 
karaniu takich sprawców występują w Carolinie ${ }^{26}$, potem w Landrechcie pruskim ${ }^{27}$, w krajowych kodeksach karnych państw niemieckich, wreszcie w k.k. Rzeszy 1871 r. (§ 370 pkt. 5). „W Bugandzie prawo to nie uważa za kradzież, gdy się weźmie u swego wodza trochę pożywienia zgodnie z zasadami «wódz nie spiera się o jedzenie», «siedziba wodza oznacza coś do jedzenia», «ten, kto zje coś, co należy do jego pana, nie jest złodziejem». Ktokolwiek przechodzi koło przygotowanego jedzenia, może bezkarnie się posilić. Podobnie w Kongu: w świetle stosunkowo niedawnego wyroku trybunału terytorialnego w Dilolo, kobieta znajdująca się w podróży ma prawo wziąć z pola trochę manioku dla głodnego dziecka. Trybunał uniewinnił oskarżoną, zganił natomiast pokrzywdzonego rolnika, który ją oskarżył o kradzież" ${ }^{28}$. Zdaniem I. Andrejewa, odmienna ocena społeczna i prawna zaborów żywności znajduje swoje odzwierciedlenie w nomenklaturze prawnej, gdyż nie nazywają się one kradzieżami. W Afryce, w prawie zwyczajowym Aszantów, jeżeli sprawca dopuszcza się czynu w rodzinie lub grupie rodowej, jego czynności nie określa się mianem „kradnie”, lecz zwyczajnie „,bierze” coś, co do niego

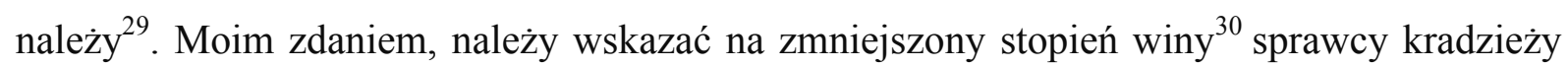
pokarmu w celu jego spożycia, która obecnie będzie kwalifikowana z art. 119 § 1 Kodeksu wykroczeń $^{31}$. Wydaje się, że przy wymiarze kary za to wykroczenie należy uwzględnić W szczególności to, czy sprawca rzeczywiście nie miał pieniędzy na jedzenie, czy tylko chciał je zaoszczędzić oraz ewentualną przyczynę ich braku np. wynikłą z przeznaczania ich na alkohol. Nie bez znaczenia jest także miejsce czynu (wielkość miejscowości i związany z tym stopień bezrobocia).

W przedwojennym piśmiennictwie podnoszono, że ,zabór cudzego mienia w celu przywłaszczenia, stanowi kradzież i ulega karze na mocy art. 250 proj. k.k. Jednakże nie każdy zabór tego rodzaju można uznać za kradzież w ścisłem znaczeniu tego wyrazu. Wszystkie niemal ustawy karne wyłączają $\mathrm{z}$ pojęcia kradzieży takie czyny, które, choć stanowią zabór w celu przywłaszczenia, nie mają jednak na widoku zwiększenia

\footnotetext{
${ }^{26}$ Constitutio Criminalis Carolina z $1532 \mathrm{r}$.

${ }^{27}$ Powszechne prawo krajowe dla państw królewsko-pruskich z 1794 r.

${ }^{28}$ Komisja Kodyfikacyjna Rzeczpospolitej Polskiej, Sekcja Prawa Karnego, Projekt wstępny części szczegółowej Kodeksu karnego, t. IV, z. 2, Lwów 1926, s. 43.

${ }^{29}$ Ibidem, s. 43.

${ }^{30}$ Pod względem przedmiotowym, pokrzywdzony ponosi taką samą szkodę finansową, jak gdyby skradziono mu tyle samo warty przedmiot niespożywczy. Analogicznie co najmniej porównywalny jest stopień zagrożenia dla bezpieczeństwa komunikacyjnego prowadzenia auta np. z 0,55 promila alkoholu w wydychanym powietrzu, a kierowania nim w stanie skrajnego niewyspania. Ustawodawca jednak tylko pierwszy przypadek uznaje formalnie za okoliczność obciążającą i zwiększa ustawowe zagrożenie karne. Wydaje się, że właśnie dlatego, że stan nietrzeźwości jest okolicznością znacznie zwiększającą winę sprawcy, niż stan skrajnego niewyspania, ale także pewnie dlatego, że można go obiektywnie zweryfikować i prawie zawsze zależy od woli sprawcy.

${ }^{31}$ Ustawa z 20.5.1971 - Kodeks wykroczeń, t.j. Dz.U. z 2015 r. poz. 1094 z późn. zm., dalej k.w.
} 
swego majątku cudzym kosztem, lecz tylko zaspokojenie chwilowej drobnej potrzeby, często po prostu zachcianki. Zerwanie jabłka z cudzego drzewa, kwiatka z cudzego klombu, grzyba lub jagody z cudzego lasu - nie może być porównane do wyciągnięcia zegarka lub portmonetki z cudzej kieszeni albo zabrania cudzego futra z przedpokoju. Postać czynu jest tu zbliżona, ale charakter jest zupełnie inny. To też należy tego rodzaju zabór wyodrębnić jako przekroczenie, zbliżone raczej do samowolnego korzystania z cudzego mienia niż do kradzieży"32. Niefortunne było w powołanym projekcie k.k. ustanowienie znamienia lekkomyślności. Wydaje się, że projektodawcom nie chodziło o znaczenie obecnie przypisywane temu terminowi (świadoma nieumyślność), gdyż kradzież może być popełniona wyłącznie z winy umyślnej. Jako przykład „kradzieży przez lekkomyślność” wskazywano ucznia, który zabiera w celu przywłaszczenia koledze ołówek ${ }^{33}$.

Nie zdecydowano się jednak na tak szerokie określenie znamion wykroczenia kradzieży. Przepis art. 55 Prawa o wykroczeniach z 1932 r. ${ }^{34}$ penalizował bezprawny zabór nieznacznej ilości owoców, warzyw lub kwiatów. Unormowania typów uprzywilejowanych kradzieży dopełniono art. $257 \S 2$ k.k. z 1932 r. (przypadek mniejszej wagi). Jeżeli sprawca zabrał z nędzy celem użycia małej wartości przedmiot pierwszej potrzeby, sąd mógł zastosować nadzwyczajne złagodzenie kary lub nawet odstąpić od jej wymierzenia. Za przykłady wskazywano kradzież kawałka chleba, drobnej kwoty pieniężnej lub innego przedmiotu małej wartości $\mathrm{w}$ celu spieniężenia go na kupienie żywności lub opału ${ }^{35}$. Kradzież „z nędzy” wyodrębniały także K.K.R. (art. 581 ust. 4) oraz K.K.N. (§ 248a). Ówcześni przedstawiciele doktryny podkreślali, że kradzieży takiej (na skutek „,upośledzenia majątkowego") nie należy utożsamiać $\mathrm{z}$ kradzieżą $\mathrm{z}$ głodu ${ }^{36}$. Wskazywali oni, że „bezpośrednio dominujący głód sprawcy lub innej osoby, jako pobudka kradzieży, może być usprawiedliwieniem działania w rozumieniu stanu wyższej konieczności; nędza natomiast stanowi okoliczność łagodzącą ustawowo wyróżnioną w stosunku do kradzieży i przywłaszczenia, usprawiedliwiającą niższy wymiar kary.” K.K.N. kwalifikował jako wykroczenie wypadek zaboru środków spożywczych W nieznacznej ilości $\mathrm{w}$ celu natychmiastowego spożycia (nędza nie była warunkiem koniecznym).

\footnotetext{
${ }^{32}$ Komisja Kodyfikacyjna Rzeczpospolitej Polskiej, Sekcja Prawa Karnego, Projekt wstępny..., s. 69.

${ }^{33}$ Ibidem, s. 69-70.

${ }^{34}$ Rozporządzenie Prezydenta Rzeczypospolitej z 11.7.1932 r. - Prawo o wykroczeniach (Dz.U. Nr 60, poz. 572)

${ }^{35}$ Komisja Kodyfikacyjna Rzeczpospolitej Polskiej, Sekcja Prawa Karnego, Projekt wstępny, s. 70.

${ }^{36} \mathrm{~W}$. Makowski, Prawo karne. O przestęsstwach w szczególności. Wykład porównawczy prawa karnego austryackiego, niemieckiego i rosyjskiego obowiązującego w Polsce, Warszawa 1924, s. 417.
} 


\section{Podsumowanie i wnioski}

Kodeks karny z 1932 r. ${ }^{37}$ stypizował tylko dwie kradzieże kwalifikowane (kradzież rozbójniczą oraz rozbój). Okolicznością kwalifikującą nie było włamanie. Nie zaaprobowano propozycji M. Siewierskiego, który stwierdził: „opierając się na wynikach praktyki w tym przedmiocie, uważam, że należy wprowadzić przedewszystkiem dwie okoliczności, kwalifikujące kradzież: użycie szczególnych środków technicznych (a zatem nie łomu lub wytrycha, lecz np. narzędzi kasiarskich) oraz działanie przestępne w organizacji”,38.

Przepis art. $257 \S 1$ k.k. z 1932 r., stanowił, że kto zabiera innej osobie cudze mienie ruchome w celu przywłaszczenia podlega karze więzienia do lat 5. Zgodnie z przepisem art. $257 \S 2$ tego kodeksu, w przypadkach mniejszej wagi sad może zastosować nadzwyczajne złagodzenia kary, a gdy sprawca z nędzy zabrał celem użycia małej wartości przedmiot pierwszej potrzeby - nawet od kary uwolnić. W art. $257 \S 3$ k.k. z 1932 r. ustanowiono względnie wnioskowy tryb ścigania kradzieży, jeżeli została popełniona na szkodę osoby najbliższej.

Kodeks karny z 1932 r., tak samo jak następne k.k. trafnie nie wprowadza expressis verbis braku zgody właściciela (posiadacza), gdyż jest on wkomponowany w znamię zaboru. Ponadto znamię to nie we wszystkich przypadkach wyznacza bezprawność zaboru. Jeżeli dana osoba ma prawo do władania rzeczą (np. komornik), to przejęcie nad nią władztwa, nawet bez zgody posiadacza, nie wypełnia znamion kradzieży (wyłączona jest wtedy bezprawność w strukturze przestępstwa).

$\mathrm{Z}$ aprobatą należy również odnieść się do braku wprowadzenia expressis verbis znamienia bezprawności działania na wzór niemieckiego k.k. z 1871 r., w którym strona podmiotowa kradzieży została określona sformułowaniem ,aby ją sobie bezprawnie przywłaszczyć”. Wprowadzanie do typów czynów zabronionych znamienia bezprawności zachowania jest uzasadnione wyłącznie w przypadkach, w których określone zachowanie jest unormowane w przepisach szczególnych. Wtedy ustawodawca posługuje się terminami „bezprawnie”, „bez uprawnienia”, „bez zezwolenia” etc.

Bezprawność kradzieży wyznacza natomiast, co do zasady, brak zgody posiadacza, a nie przepisy szczególne. Z tego powodu wprowadzanie klauzuli bezprawności działania należy uznać za zbędne.

\footnotetext{
${ }^{37}$ Rozporządzenie Prezydenta Rzeczypospolitej z 11.7.1932 r. - Kodeks karny, Dz.U. Nr 60, poz. 57.

${ }^{38}$ M. Siewierski (w:) Włodzimierz Sokalski (red.), op. cit., s. 8.
} 
W kontekście braku wprowadzania do przedwojennego ustawodawstwa typu wykroczenia kradzieży w oparciu o znamię kwotowe wartości rzeczy (jak ma to miejsce obecnie) pozytywnie należy ocenić unormowanie typu uprzywilejowanego kradzieży w art. 257 § 2 k.k. z 1932 r. (zabór z nędzy w celu użycia małej wartości przedmiotu pierwszej potrzeby). Natomiast aktualnie, w związku z kwotową kontrawencjonalizacją kradzieży, istnienie takiego typu uprzywilejowanego byłoby niecelowe, gdyż kradzież mienia, która pod rządami k.k. z 1932 r. wypełniała znamiona typu uprzywilejowanego obecnie będzie wypełniać znamiona wykroczenia (art. 119 k.w.) i daje to wyraz mniejszemu bezprawiu takiej kradzieży. ${ }^{39}$ Ponadto karygodność takiej kradzieży wydaje się wyższa niż $\mathrm{w}$ okresie międzywojennym ze względu na znaczące rozwinięcie systemu socjalnego państwa oraz świadczenie pomocy przez organizacje społeczne. Tzw. kradzież z nędzy w okresie międzywojennym mogła być na pograniczu stanu wyższej konieczności, jeżeli sprawca kradł jedzenie albo drewno w celu ochrony swojego zdrowia, które było „prawie bezpośrednio" zagrożone, gdyż nie miał innej możliwości uzyskania tych rzeczy. Obecnie tak nie jest, swoboda decyzyjna sprawcy nie jest na tyle ograniczona. Poza tym taka kradzież wypełnia znamiona wykroczenia i jej mniejszy stopień bezprawia ma wyraz w przypisaniu odpowiedzialności za wykroczenie a nie występek.

\footnotetext{
${ }^{39}$ Abstrahując od wyjątkowej możliwości „złączenia” takich wykroczeń czyn ciągły (art., 12 k.k.). Możliwości nadzwyczajnego wymiaru kary za czyn z art. 278 § 1 k.k. są na tyle duże, że reakcja karna może być adekwatna do stopnia winy i bezprawia również w takim szczególnym przypadku.
} 


\section{Summary}

The paper analyses drafts of penal codes (1920-1932) which reference to theft crime. The drafts have desisted casuistry, which had occurred in previous regulation. This contribution presents dogmatic issues related to the feature "consent of authorized person (owner, holder)". The author criticizes distinction of this feature in regulation because it contains in term "taken someone else`s movable property". The paper sees controversial issues of "lawlessness of taken someone else's movable property" and "lawlessness of purpose of appropriation", which means intention of taking someone else's movable property in order to treat an object of crime like own. The author criticizes distinction of this feature in drafts of penal codes because prerequisite of lawlessness is display in description of crime in another situations. The feature "lawlessness of appropriation" has been in theft crime in StGB since 1871 and it was also in some of polish penal codes drafts (1920-1932). The paper analyses aggravated and mitigated circumstances of theft. The author underlines wide scope of regulation of theft in legislations until beginning of XIX century, which patterned oneself on Roman law. The fraud, theft (in current meaning) and appropriation crimes have been distincted step by step in XIX century. It caused necessity to create new features.

\section{Tomasz Tyburcy}

Doktor nauk prawnych. Absolwent Wydziału Prawa i Administracji Uniwersytetu Kardynała Stefana Wyszyńskiego w Warszawie oraz Studiów Doktoranckich na Wydziale Prawa i Administracji Uniwersytetu Warszawskiego (Instytut Prawa Karnego, Katedra Prawa Karnego). Autor publikacji z zakresu prawa karnego. Specjalizuje się w analizie struktury przestępstwa, przestępstwach przeciwko mieniu oraz bezpieczeństwu w komunikacji. 